\title{
Hybrid Voters: How the Politics in the Home and the New Country Influences External Voters
}

\section{Marco Ognibene \& Emilien Paulis}

To cite this article: Marco Ognibene \& Emilien Paulis (2021): Hybrid Voters: How the Politics in the Home and the New Country Influences External Voters, Representation, DOI: 10.1080/00344893.2021.1978531

To link to this article: https://doi.org/10.1080/00344893.2021.1978531

+ View supplementary material $匚$

曲 Published online: 26 Sep 2021.

Submit your article to this journal $\asymp$

Q View related articles $₫$

View Crossmark data 


\title{
Hybrid Voters: How the Politics in the Home and the New Country Influences External Voters
}

\author{
Marco Ognibene (D) and Emilien Paulis \\ Political Science Department (Cevipol), Université libre de Bruxelles, Brussels, Belgium
}

\begin{abstract}
Based on 20 years of election data gathered for 6 European countries, this article analyses how the non-resident citizens vote from abroad in the elections of their origin country. Our mediation model demonstrates that the external vote share of a party is dependent on the support for this party in the homecountry before the election and the support registered for ideologically close parties in the new country of residence at the same moment. Our results put thus forward that external voting choices are hybrid: they mostly reflect the political context of their 'home' origin country, but also mirror politics in the 'new' country of residence. Furthermore, the article shows that the link between incumbency and the share taken by a party among the external community is not direct but mediated by how much is this party supported in the home-country, and how much ideologically similar parties are supported in the host-country. This finding further confirms that the flow of public opinion in the home and the new country both shape the choices that are made by external voters.
\end{abstract}

\section{KEYWORDS}

Electoral behaviours; external voting choices; Europe; mediation model

\section{Introduction}

Over the last two decades, States have continuously revised whether and how people who make their permanent residence outside the boundaries of their country of origins may participate in their home-country elections (Bauböck, 2005; Ellis, Navarro, Morales, Gratschew, \& Braun, 2007; Hutcheson \& Arrighi, 2015; Lafleur, 2015; Turcu \& Urbatsch, 2014). Therefore, the literature on external voting has expanded and mostly focused on the content, the application, and the diffusion of such external voting rights across countries (Bermudez \& Lafleur, 2015; Earnest, 2015; Ellis et al., 2007; Gamlen, 2018; Hartmann, 2015; Hutcheson \& Arrighi, 2015; Jaulin \& Smith, 2015; Lafleur, 2011b, 2015). While these contributions demonstrate that implementation of such enfranchisement rights contrasts sharply from one country to one another, other works have turned to question how they could boost or hinder external voters' turnout in home-country elections (Bermudez, 2010; Lafleur \& Calderon, 2011; McIlwaine \& Bermudez, 2015; Tager, 2006; Tintori, 2012), which is overall low (Kivisto, 2001; Waldinger \& Fitzgerald, 2004). Furthermore, 
party-determinants (Burgess \& Tyburiski, 2020; Kernalegenn \& van Haute, 2020; Østergaard-Nielsen \& Ciornei, 2018; Rashkova \& Van Der Staak, 2019), and individual-determinants (Guarnizo, Portes, \& Haller, 2003; Leal, Lee, \& McCann, 2012; Morales \& Giugni, 2011) have also been approached to explain why this specific sub-group of voters mobilise in home-country elections.

Yet, although the literature provides substantial knowledge about 'why' States enfranchise citizens living abroad, and 'why' these external citizens mobilise (or not) in the elections of their home-country, the study of the 'how', i.e. the choices expressed by external voters, remains still quite limited (Goldberg \& Lanz, 2019). The main reason is that the existing research 'mostly concentrates on normative arguments. The comparative studies that do exist are too broad and fall short of explaining how expatriate populations vote' (Sevi, Mekik, Blais, \& Çakır, 2020, p. 5). Therefore, this article relies on a comparative design to shed light on a fundamental but yet under-considered question: how do non-resident citizens behave in elections of their home-country? More specifically, how do the political contexts of the 'new' and the 'home', origin countries help to explain the way these non-resident citizens behave when they take part in the elections of their home-country?

To answer these questions, the article relies on the collection and analysis of aggregate election data. We undertake a cross-country analysis of European external voting choices in 6 home-countries from which the non-resident voters originate (Croatia, Czech Republic, France, Italy, Poland, and Romania), 28 European host-countries where they have settled (the EU 27 Member-States + the UK), covering more than 20 years of elections (from 1995 to 2019). The goal of this comparison across countries and elections is to make emerge regular patterns in the choices expressed among European external voters, and thereby enhancing our understanding of external voting in Europe. Since the analysis is based on aggregate data, the strategy to depict the effect of home and new country politics on external voters is to look at two proxies: party support and incumbency (in the home and the new country). The analysis uses two simple mediator models which assess whether the association between incumbency and the external voting is actually mediated by the party support expressed by the electorates in the home (for the very same party) and the new country (for ideologically similar parties), thereby capturing the influence of both contexts. Indeed, if external voters are influenced by their home-country politics, how a party is supported at home before the election should be similarly predictive of the external vote share of this party. From that, if the government participation of a party is positively evaluated by the home electorate, translating into higher voting intention in the polls, this party is expected to score higher among the external voters, showing that they remain quite connected to their home community. A similar pattern is expected for the new country of residence. If external voters are affected by the new context, how a party is supported from abroad will be predicted by the support expressed for ideologically similar parties operating in the new environment. Hence, if an incumbent ideologically close party is positively evaluated in the new country, translating into higher electoral performances, then the score of a similar party running the home election is expected to increase, emphasising that external voters could also follow the behaviours of the voters living in their new country of residence. 


\section{State of Art}

\section{Enfranchisement of External Voting Rights}

The literature on external voting - i.e. about the vote of non-resident citizens in their home-country elections - focusses mainly on the extension of election rights to this specific sub-part of the population (e.g. Ellis et al., 2007; Lafleur, 2015). Many studies analysed the (constraining) requirements to register as an external voter, the procedures to cast vote, or still how the adoption of these dispositions diffused across countries (Belton, 2019; Brand, 2010; Earnest, 2015; Ellis et al., 2007; Hartmann, 2015; Jaulin \& Smith, 2015; Lafleur, 2011 b, 2015). Country-specific factors related to the history and nature of the relationship between the government and emigrants determine the introduction of external voting practices in a country (Collyer, 2014). There is also a general tendency for liberal norms to diffuse through the international system. Countries have higher chances to enfranchise their diaspora if neighbours have already enacted external voting rights (Turcu \& Urbatsch, 2014). The liberalisation of such rights is often described as a means to foster the link to their abroad citizens and favour economic or political remittances, for instance, through providing support for the incumbent government (Lafleur, 2011b; Lafleur \& Calderon, 2011; Turcu \& Urbatsch, 2014). Besides, many scholars addressed the normative considerations behind the adoption of external voting arrangements, reading this evolution in the light of new extra-territorial citizenship conceptions (Arrighi \& Bauböck, 2017; Bauböck, 2005; Fox, 2005; Rubio-Marin, 2006).

\section{External Turnout}

Beyond the adoption of external voting rights, the literature questioned why would nonresidents participate in the elections of their home-country. First, scholars analysed the impact of institutional and voting procedures on external turnout. External voting arrangements such as registration and postal voting tend to modify the significance of predictors that are considered to have a 'crystal clear' association with the turnout of resident national citizens (Ciornei \& Østergaard-Nielsen, 2020). In addition to the legal framework, other macro, contextual variables related to the home (Brand, 2014) or the new environment turn to affect the level of external voters' mobilisation, such as the hostcountry immigration policies or its general level of democratisation (Ciornei \& Østergaard-Nielsen, 2020; Sevi et al., 2020). Second, party-level factors such as the efforts made by national parties to mobilise across the borders or the level of external electoral competition are shown to boost external turnout (Burgess, 2018; Jaulin, 2016; Kernalegenn \& van Haute, 2020; Østergaard-Nielsen, Ciornei, \& Lafleur, 2019; Østergaard-Nielsen \& Ciornei, 2018; Rashkova \& Van Der Staak, 2019). Finally, from an individual point of view, the socio-demographic profile (e.g. gender, age, educational attainment, level of income), the political attitudes (political interest, party identification), the number of years of residence, the pre-migration political participation, the strength of voters' ties to their country of origin and with compatriots who have not left, or still the political and civic engagement in the new country of residence are stressed as shaping individual turnout the elections of their home-country (Boccagni, 2011; Chaudary, 2018; Escobar, Renelinda, \& McCann, 2015; Finn, 2020; Lafleur \& SanchezDominguez, 2015; Leal et al., 2012). 


\section{External Voting Choices}

Although extant research provides a good knowledge of 'why' voting from abroad, much less is said about 'how' citizens vote once they have left (Goldberg \& Lanz, 2019). Yet, how would they vote in the elections of their country of origin when they decide to do so? It may be that the behaviours of external voters are mainly explained by the context of origin as they follow a transnational pattern (Sevi et al., 2020). In that perspective, external voters reproduce relatively similar voting patterns than the citizens who instead have not left. This would be because most migrants do not completely disconnect with their homecountry but maintain stable and long-lasting relationships through different activities (Faist, 2000; Itzigsohn, Dore Cabral, Medina, \& Vazquez, 1999; Vertovec, 1999). This transnational approach is rooted in the sociological literature that treats migrants' social, economic, and political remittances toward their origin country (Guarnizo et al., 2003; Portes, 1998). Politically, migrants have an interest to be involved not only in the new country of residence but also in their home-country (Bauböck, 2003). They keep political ties with their home community by belonging to civic or political organisations or simply voting in home elections, which is the lowest demanding form of transnational political activity (Guarnizo, Chaudary, \& Sørensen, 2017; Lafleur \& Sanchez-Dominguez, 2015). Therefore, if transnationalism is what characterises the voting behaviours of external voters, the political context from which they originate should be one source of explanation when it comes to the parties they vote for.

A substantial aspect in that regard is that party incumbency could matter. Influenced by rational choice voting theories (Blais, 2000) and the well-developed literature on the positive (Ban, Llaudet, \& Snyder, 2016; Dahlgaard, 2016; Fiva \& Smith, 2018; Salas, 2016) and negative (Klasnja \& Titiunik, 2017; Uppal, 2009) incumbency effects among the national electorate, several studies question how being in government impacts the likelihood for candidates/parties to score higher or lower among external voters. Some authors demonstrate that, when the context in the country of origin is overall favourable, external citizens tend to vote for incumbent parties, like their national fellows at home. Nonetheless, the analyses suggest also that they could vote, proportionally, even more for these parties than internal voters (Boccagni \& Ramirez, 2013; Mencutek, 2015). Furthermore, as for the role of incumbency among the national electorate, there are also contrasting evidence for external voters. Some pieces of research put forward a negative effect and the fact that external voters are more inclined to favour opposition parties, thereby standing out from national voters (Battiston \& Mascitelli, 2008; Goldberg \& Lanz, 2019; Lawson, 2003). Moreover, both outcomes are found in the external community at the same time. For instance, Sevi et al. (2020) showed that American Turkish opt for opposition parties, whereas European Turkish vote rather for the incumbent party, like their national fellows. The positive or the negative effect of incumbency would strongly depend on where external voters are located, i.e. their new country of residence, and the relationship between the new and the origin countries.

What these studies share in common is to emphasise that the voting behaviours of external citizens are not always fully transnational, as they can diverge within the external community or with the national group of voters. External voters can favour more importantly some choices compared to the national electorate or to their other external fellows (Fidrmuc \& Doyle, 2006; Goldberg \& Lanz, 2019; Lafleur \& Sanchez-Dominguez, 2015). 
Therefore, it may be that the new context of residence influences the choices that are made from abroad in home-country elections. External voters may converge toward the way citizens express themselves in the new country of residence. In sociology, such an influence of the new context is depicted by individual-level theories as the 'resocialisation approach'. The latter is interested in how migrants behave in their new country of residence, as well as how they integrate dominant attitudes and norms once they settled in a new context. These contributions usually explore the political integration of migrants in their new country: why and how they participate in this new context, as well as whether the States that host them put incentives or barriers to their electoral mobilisation (Crissey \& File, 2012; Jones-Correa, 2001; Knott, 2017; Lafleur, 2011a, 2015). Yet, the context of the new country impacts also how they remain linked and engaged in their home-country politics (Escobar et al., 2015). Already in early migration sociological works, Brown (1988) found for instance that migrants moving from one to another region of the US tended to produce a voting behaviour and a party identification congruent with the citizens living in the new host region. Considering European and international migrants, a stronger incentive towards the effect of the new context in home-country elections can be assumed. They generally move for a better personal or professional situation, which makes them more inclined to 'renew' their political attitudes and behaviours (Finifter \& Finifter, 1989). In addition, as a by-product of exposure and social influence, migrants become more similar to the population of their new location, while increasingly sharing the same assessments of host-country institutions (Nanestad, Paldam, \& Rosholm, 2003). The validity of explanatory models based on the new context of residence have been more specifically demonstrated regarding external voting choices. The migrants' political preferences can change significantly after the migration and hence adapt their behaviour in home-country politics according to the political norms and attitudes prevailing in the new country of residence (Fidrmuc \& Doyle, 2006; Sevi et al., 2020). Therefore, if the 're-socialisation' is what characterises external voting choices, the political context in the new country of residence should be a second source of explanation for the choices made by external voters in home elections. Hence, the way people are supporting parties in this new context should help to predict the external vote share taken by ideologically similar parties running the home election. In addition, if incumbent parties make a good job in the new country and are rewarded by the electorate, external voters could all the more seek for parties supporting a similar political project for their home-country.

\section{Hypotheses}

\section{The Influence of the Home-Country}

The behaviour of external voters is expected to reflect the connections and information that these non-residents keep with their home-country. Therefore, external voting choices should closely follow the way national citizens in the home-country support political parties. Hence, the party support expressed by the home population in opinion polls during the months preceding the election is expected to turn into a significant predictor of its support among the external community, at least as significant as it does with the national one (Dahlgaard, Hansen, Hansen, \& Larsen, 2017). Furthermore, from that 
and compared to previous research, the incumbency of a party is expected to affect only indirectly its vote share abroad. Indeed, being a governing party should not directly impact the score of this party abroad, but first affect its share in opinion polls, positively or negatively depending on voters' evaluations of government performances. Subsequently, the results in the pre-electoral polls should turn into predicting the external vote share of this party. This could mean that external voters do not vote blindly in home-country elections but their choices are informed and fed by home-country politics since they closely follow the evaluations of the parties in the polls and the opinions expressed by the home electorate before the election (Figure 1).

The incumbency of a party in the home-country will affect the support for this party among the national voters (H1.1), which, in turn, will impact the support for this party among the external voters (H1.2.). In other words, the support for a party in the home-country is the mediator of the relationship between this party incumbency and the external vote share of this party (H1.3.).

\section{The Influence of the New Country}

While migrants' political participation is shown to be influenced not only by the home but also at the same time by the new country of residence (Bermudez, 2010; Chaudary, 2018; Fitzgerald, 2004; Goldberg \& Lanz, 2019; Guarnizo et al., 2003; Levitt \& Glick Schiller, 2008; Morawska, 2003; Tsuda, 2012), the behaviours of external voters are expected to mirror also the new connections and information that they received from the new country. Therefore, the composition of the political landscape and the performances of political parties in the host-country, which can be conceived as a proxy of this country's voting behaviours, should turn into a predictor of the choices expressed by external voters in their home-country elections. Indeed, external voters could seek, in home-country elections, for parties that are similar to the ones performing well in the host-country, thereby following also the flow of the public opinion in their new country of residence. To assess the influence of the new political context on the external voting choices, the incumbency and the results of the parties in the host-country are considered in the same consequential logic as for the home context. The relationship between the incumbency of a party in the host-country and the external vote share

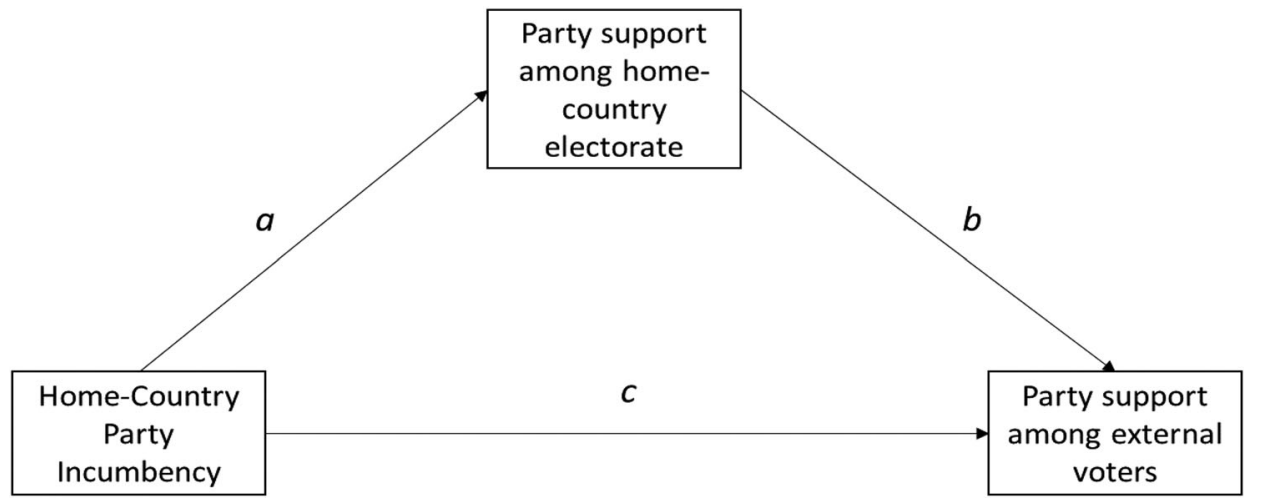

Figure 1. Simple mediation model for the influence of the home-country politics. 


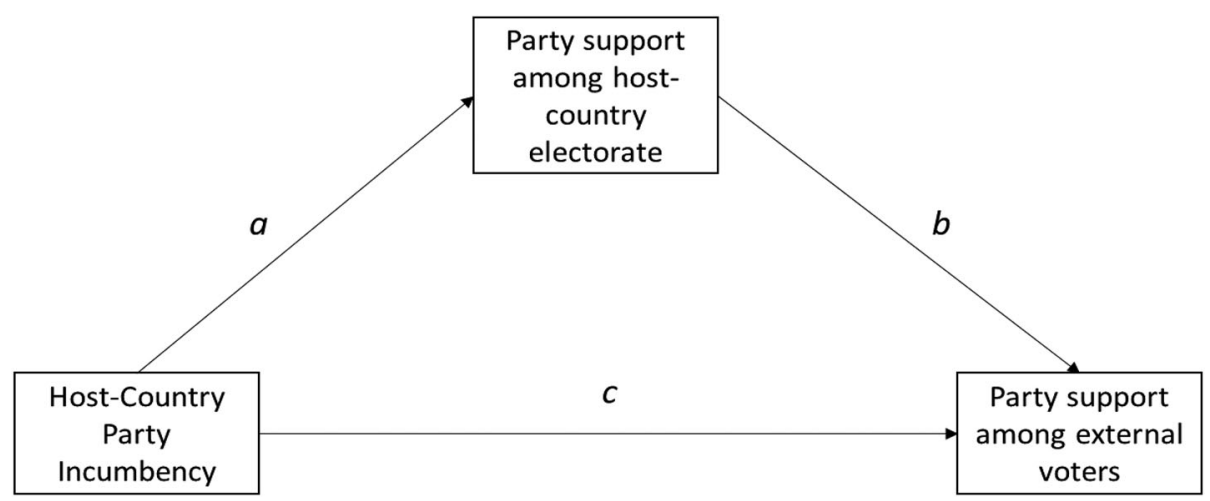

Figure 2. Simple mediation model for the influence of the new country politics.

taken by the ideologically similar party running the home election is expected to be indirect and mediated: incumbency will first influence whether parties in the new country have high or low electoral performances, depending on the rewards or sanctions received in elections by the voters of the new country. Subsequently, their electoral results should turn into predicting the external vote share of ideologically similar parties running the home election. This could suggest that external voters seek in the home elections for ideologically close parties to those that are positively evaluated by the electorate in their new country, stressing the influence of the new context (Figure 2).

The incumbency of a party in the host-country will affect the support for this party among the national voters of this country (H2.1), which, in turn, will impact the support for an ideologically similar party among external voters (H2.2). In other words, the support for a party among the host-country electorate is the mediator of the relationship between this party incumbency and the external vote share taken by the ideologically similar party at home (H2.3.).

\section{Empirical Strategy}

\section{Data and Case Selection}

As Goldberg and Lanz (2019, p. 2) fairly argued, 'in electoral research, it is hard to perceive of a similarly large group of voters that is as understudied as the citizens living abroad'. External voting choices have been largely underexplored due to one empirical limitation: a lack of individual-level data. Election surveys are generally based on national samples in which non-resident citizens are not considered. If the lack of scientific interest could just be because this part of the electorate is insignificant, it is not totally justifiable. The proportion of 'expats' has dramatically increased in European democracies. In 2017, 3.8\% of EU working-age citizens (20-64 years old) resided in another EU Member State than that of their citizenship, compared to 2.5\% in 2007 (Eurostat, 2018).

In the absence of available individual-level data on external voters that are comparable across time and countries, our empirical strategy has been to work with aggregate-level election data. We gathered publicly available electoral results, where external voting 
Table 1. Countries and elections' coverage of the study.

\begin{tabular}{|c|c|c|c|c|c|}
\hline \multirow{2}{*}{$\begin{array}{l}\text { Home- } \\
\text { countries }\end{array}$} & \multicolumn{3}{|c|}{ Elections } & \multirow[t]{2}{*}{$\begin{array}{l}\text { Host- } \\
\text { countries }\end{array}$} & \multirow{2}{*}{ Elections } \\
\hline & Parliamentary & Presidential & European & & \\
\hline Croatia & 2007, 2011, 2015 & - & - & $\begin{array}{r}27 \text { other } \\
\text { EU MS }\end{array}$ & $\begin{array}{l}\text { The last host-country legislative or } \\
\text { European election before the } \\
\text { home-country election under } \\
\text { consideration }\end{array}$ \\
\hline $\begin{array}{l}\text { Czech } \\
\text { Republic }\end{array}$ & 2013,2017 & 2018 & - & Idem & Idem \\
\hline France & - & $\begin{array}{c}1995,2002 \\
2007,2012 \\
2017\end{array}$ & - & Idem & Idem \\
\hline Italy & $\begin{array}{l}2006,2008,2013 \\
2018\end{array}$ & - & $\begin{array}{r}2004,2009 \\
2014,2019\end{array}$ & Idem & Idem \\
\hline Poland & $\begin{array}{l}2001,2005,2007 \\
2011,2015\end{array}$ & - & $\begin{array}{l}\text { 2009, 2014, } \\
2019\end{array}$ & Idem & Idem \\
\hline Romania & 2012,2016 & - & $\begin{array}{l}\text { 2009, 2014, } \\
2019\end{array}$ & Idem & Idem \\
\hline
\end{tabular}

choices could be split by new countries of residence. This data structure makes then possible to put in relation the electoral results of parties (and implicitly voting choices) in both the home and the new country. Nonetheless, this information was reachable only in 6 European countries (see the data coverage in Table 1): Croatia, Czech Republic, Italy, France, Poland, and Romania. Interestingly, these 6 European countries present among the highest shares of citizens living abroad (Eurostat, 2018).

As indicated in Table 1, the scope for the countries of residence is limited to the $27 \mathrm{EU}$ Member States (+the UK). We have decided to stick to European democracies for a better congruence in the parties' ideological classification with the home and the new country, which is important to address the influence of the new political context from aggregate electoral results (see further). Furthermore, many existing studies on external voting choices are based on Latin American cases, whereas European countries as a specific focus of research for both the home and the host-countries are much less explored (see some single-case studies' exceptions, e.g. Fidrmuc \& Doyle, 2006 or Goldberg \& Lanz, 2019) and compared.

\section{Dependent Variable: The Support for a Party among External Voters (VoteShareAbroad)}

The abroad election results of each home-country have been disaggregated by countries of residence to build the main dependent variable (VoteShareAbroad). The latter measures the vote share registered by a party $j$ in a given foreign country, based on the data extracted from the 6 home-countries' national ministries and electoral archives. ${ }^{1}$ Given how it improves the results of the estimation (Honaker et al., 2002), the variable has then been transformed into the following logarithmic form, where vote share (Vij) corresponds to the fraction of votes obtained in the election $i$ by the party $j$ and varies from $-\infty$ to $\infty$ :

$$
\text { VoteShareAbroad }(\log )=\ln \left[\frac{\mathrm{Vij}}{1-\mathrm{Vij}}\right]
$$




\section{Independent Variables}

\section{Incumbency}

The two first explanatory variables are binary and measure the government participation in the 6 home and 28 host-countries retrieved from the Parlgov dataset. ${ }^{2}$ 'Incumbency home' takes the value of 1 for a party $j$ that was in government in the home-country before they ran the election of interest, and 0 for a challenger party. 'Incumbency host' takes the value 1 when a party $j$ in the new country of residence was incumbent at the last election preceding the home election of interest, and 0 when it was a challenger party.

\section{Mediator Variables}

\section{Support for a Party in the Home-Country (VoteSharePolls)}

To map the influence of home politics, we centralised information about the party support expressed in opinion polls preceding all the elections considered in the 6 home-countries of interest (see Supplementary Information for the sources). Although limitations remain, pre-election polls are shown to be a relatively good proxy to capture the state of the public opinion before an election (Berinsky, 2017; Morwitz \& Pluzinski, 1996). The variable 'VoteSharePolls' corresponds to the mean vote share registered by a party $j$ in the pre-electoral polls administered in the country of origin the last month before the election. The variable has then been transformed into a logarithmic formula:

$$
\text { VoteSharePolls }(\log )=\ln \left[\frac{\text { Vijpolls }}{1-\text { Vijpolls }}\right]
$$

\section{Support for a Party in the New Country of Residence (VoteShareHost)}

To explore the impact of the new country of residence, the dataset includes the results of the closest national elections held in each of the other 27 host-countries. ${ }^{3}$ The variable 'VoteShareHost' is the vote share registered by a party $j$ in the last election held in the new country of residence before the home-country election of interest. Again, the variable has been transformed into a logarithmic form:

$$
\text { VoteShareHost }(\log )=\ln \left[\frac{\text { VijforeignParty }}{1-\text { VijforeignParty }}\right]
$$

To find a match between the party preferences at home and in the new country, all the parties were organised according to their ideological families ${ }^{4}$ by merging the classification of the Manifesto Project and ParlGov into broad categories.

\section{Modelling Strategy}

The main purpose of this study is to assess whether external voting choices are shaped at the same time by home and host-countries' political contexts. To do so, along with direct effects, more complex, indirect effects have been conceived and tested through the combination of two simple mediation models (Hayes, 2018). We model external voting choices as resulting from a causal sequence: the antecedent incumbency in the home 
and host contexts will influence party support in both types of countries (positively or negatively depending on both electorates' evaluations), which will subsequently impact the vote share taken among external voters. Since independent variables are different depending on the home or the host-country, a seemingly unrelated regression (SUR) has been applied to our data. This modelling technique is well suited to compare multiple equations at the same time and ensure the statistical efficiency of the estimation (Hicks \& Tingley, 2011). Moreover, compared to the assessment of indirect effects possible with structural equation modelling, the SUR allows to include also categorical control variables (Green, 2017). In this study, the direct and indirect effects of incumbency are estimated through three different equations ${ }^{5}$ (two for the mediators and one for the final outcome), which are reported below:

$$
\begin{aligned}
& \text { VoteSharePolls }(\log )=M_{1}=\alpha_{m 1}+\beta_{1} \text { IncumbentHome }+e_{m 1} \\
& \text { VoteShareHost }(\log )=M_{2}=\alpha_{m 2}+\beta_{1} \text { IncumbentHome }+e_{m 1}
\end{aligned}
$$

$$
\begin{aligned}
\text { VoteShareAbroad }(\log )= & Y=\alpha_{y}+\beta_{y 1} \text { VoteSharePolls }(\log )+\beta_{y 2} \text { IncumbentHome } \\
& +\beta_{y 3} \text { VoteShareHost }(\log )+\beta_{y 4} \text { IncumbentHost }+e_{y}
\end{aligned}
$$

A simultaneous double simple mediation model (summarised in Figure 3 below) was created and tested through the STATA16, with 5.000 bootstrap samples and $95 \%$ of confidence intervals. The significant indirect effects presented in Figure 3 were assessed through 95\% bias-corrected and accelerated bootstrap confidence intervals that do not include zero (Hayes, 2018).

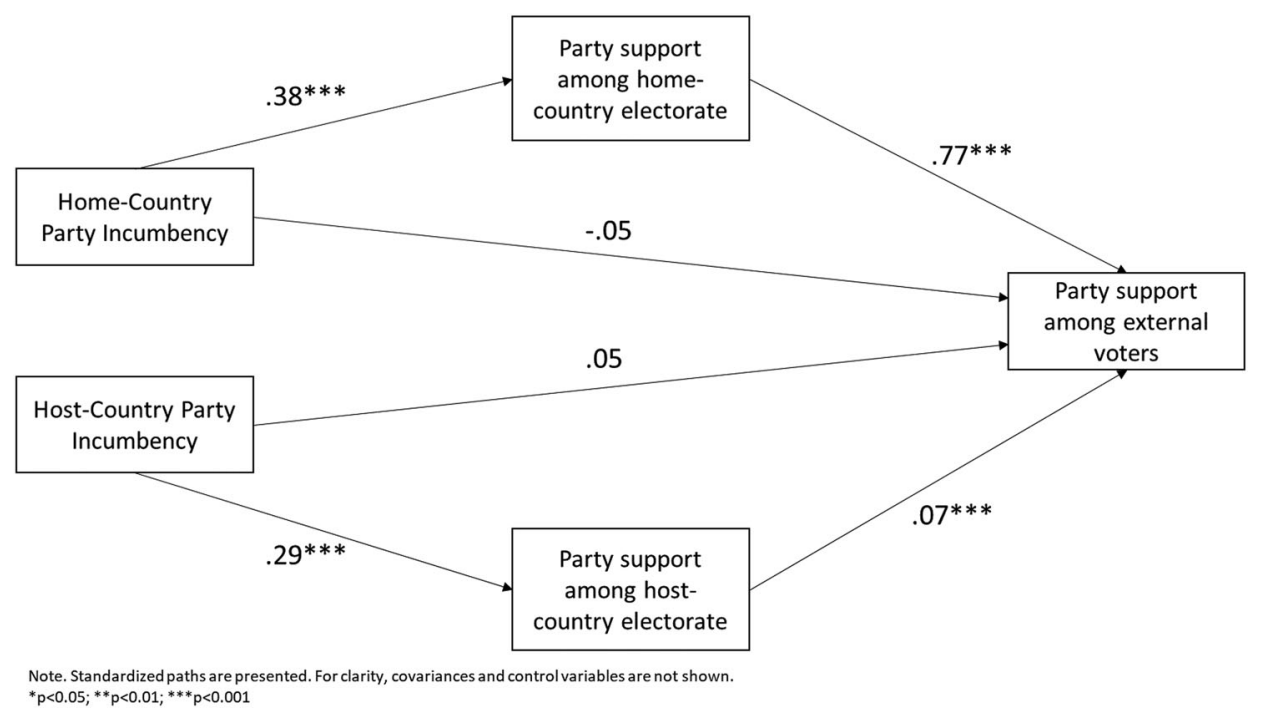

Figure 3. Simultaneous double mediation model for the influence of both the home and new country politics. 


\section{Analysis}

\section{The Influence of Home Politics}

Regarding the effect of the home context, Table 2 shows that VoteSharePolls $(\log )$ has a complete mediating effect on the relationship between Incumbency Home and VoteShareAbroad $(\beta=0.2967$, BootLLCI $=0.2385$, BootULCI $=0.3553$ with lower and upper bound of accelerated bootstrap confidence intervals doesn't contain 0$)$. It means that being an incumbent party boosts the vote share in pre-election polls (compared to a challenger party), and this higher score translates into a higher propensity to score among external voters. This finding confirms the relevance of the general model $^{6}$. When a party is positively forecasted in the polls and has higher support among the national population, the external voters seem to vote more for this party, meaning that they mostly adopt the same behaviours as their national compatriots. Furthermore, the model emphasises that government participation matters indirectly. The incumbency has first the power to affect the support of a party among the home population. If an incumbent party is overall well supported by the national population in the polls, meaning that its government participation is evaluated positively by the home-voters, then its external vote share tends to increase. This finding confirms that there is an effect of the home political context in the voting choices expressed by external citizens. It could mean that that the 'floating effect' between opinions expressed in polls and opinions expressed in elections (Dahlgaard et al., 2017) work also for external voters.

\section{The Influence of the New Country}

As far as the impact of the new context is concerned, VoteShareHost $(\log )$ has a complete mediating effect on the relationship between Incumbent Host and VoteShareAbroad ( $\beta=$ 0.0201 , BootLLCI $=0.0110$, BootULCI $=0.0326$ ). Like in the home-context, an incumbent party in the host-country is more likely to reach higher support in national elections of this country (compared to a challenger party), which in turn affects positively the external vote share obtained by the party that is the closest ideologically in the home political offer. This pattern suggests that external citizens express voting choices that are also influenced by their new political environment: they opt-in home elections for a party that is ideologically similar to one well evaluated in their new country of residence. This finding based on comparative evidence is in line with the case studies showing that the context of the host-country impacts also how migrants remain politically active in their home-country politics (Escobar et al., 2015; Lafleur \& Sanchez-Dominguez, 2015).

Table 2. Indirect effects based on 5,000 bootstrap samples for the external voting choices.

\begin{tabular}{lcccc}
\hline & & & \multicolumn{2}{c}{$\begin{array}{c}95 \% \text { confidence } \\
\text { interval }\end{array}$} \\
\cline { 3 - 5 } Indirect Paths: & Effect & BootSE & BootLLCI & BootULCl \\
\hline Incumbent Home $->$ VoteSharePolls $(\log )->$ VoteShareAbroad(log) & 0.2967 & 0.0299 & 0.2385 & 0.3553 \\
Incumbent Host $>$ VoteShareHost $(\mathrm{log})->$ VoteShareAbroad $(\log )$ & 0.0201 & 0.0054 & 0.0110 & 0.0326 \\
\hline
\end{tabular}

Note: BootLLCl $=95 \%$ bias-corrected and accelerated bootstrap lower bound confidence interval; BootLLCI $=95 \%$ biascorrected and accelerated bootstrap upper bound confidence interval; BootSE = bootstrap standard error. 


\section{Robustness Check}

Our results raise two additional questions. First, pre-electoral polls are based on national samples in which communities of non-resident citizens are excluded. Therefore, are these polls really as good predictor of the external vote share of a party as they are for the share among the national community? In other words, do the polls predict the voting behaviour of non-resident citizens as good as for nationals (meaning that it constitutes a good proxy for the effect of the home political context)? Second, if the external vote share of a party follows the share of ideologically similar parties in the new country of residence, can we observe the same strength in the predictive association than with the home opinion polls? Put differently, is the public opinion in the host-country as good predictor as the home public opinion? Or is the influence of the new context just a spurious relationship?

To answer these questions and increase the validity of our findings, we conducted an additional multivariate regression reported in Table 3. It considers two dependent variables in a logarithmic form: VoteShareAbroad (as in our main model) and VoteShareHome, which is the vote share of the same party registered among the citizens residing in the home-country. Regarding the independent variables, we used all the same variables than in our general model. The outcomes confirm that the variable related to the homecontext (i.e. the share of a party in the polls) strongly predicts the share taken by this party in the national and external communities. Yet and not surprisingly though, the magnitude recorded for non-resident citizens is lower than for the residents (respectively

Table 3. Multivariate regression. Home and new country politics' influence on external and national voters.

\begin{tabular}{|c|c|c|}
\hline & VoteShareAbroad Model & VoteShareHome Model \\
\hline IncumbentHome & $-.05(0.04)$ & $-.10^{* * *}(0.02)$ \\
\hline VoteSharePolls(log) & $.77^{* * *}(0.02)$ & $.97^{* * *}(0.01)$ \\
\hline IncumbentHost & $.05(0.04)$ & $.01(0.02)$ \\
\hline VoteShareHost(log) & $.07^{* * *}(0.02)$ & $-.007(0.01)$ \\
\hline \multicolumn{3}{|c|}{ Ideological Family (Ref. Conservative) } \\
\hline Extreme-Right & $-1.05^{* * *}(0.07)$ & $-.14^{* * *}(0.04)$ \\
\hline Green & $.30 * *(0.11)$ & $-.25^{* * *}(0.05)$ \\
\hline Liberal & $.04(0.07)$ & $-.25^{* * *}(0.04)$ \\
\hline Radical Left & $-.83^{* * *}(0.10)$ & $-35^{* * *}(0.04)$ \\
\hline Social Democratic & $-.87^{* * *}(0.05)$ & $-.17^{* * *}(0.03)$ \\
\hline Other Parties & $-.48^{* * *}(0.09)$ & $-.10 *(0.04)$ \\
\hline \multicolumn{3}{|c|}{ Geography - Home (Ref. Western Country) } \\
\hline Eastern Country - Home & $-.36^{* * *}(0.06)$ & $-.22^{* * *}(0.03)$ \\
\hline \multicolumn{3}{|c|}{ Geography - Host (Ref. Western Country) } \\
\hline Eastern Country - Host & $.02(0.04)$ & $.02(0.02)$ \\
\hline \multicolumn{3}{|c|}{ Type of Election (Ref. Legislative) } \\
\hline Presidential & $-.76^{* * *}(0.10)$ & $-.45^{* * *}(0.04)$ \\
\hline European & $-.19^{* * *}(0.04)$ & $-.19 * * *(0.02)$ \\
\hline GDP Growth - Home & $.003(0.01)$ & $.0002(0.004)$ \\
\hline Unemployement Rate - Home & $.03^{* * *}(0.005)$ & $-.002(0.002)$ \\
\hline GDP Growth - Host & $.0003(0.004)$ & $-.002(0.002)$ \\
\hline Unemployement Rate - Host & $.01 *(0.003)$ & $.0004(0.002)$ \\
\hline External Voting Rights - Home & $-.02^{* * *}(0.004)$ & $-.01^{* * *}(0.002)$ \\
\hline Constant & $36.54^{* * *}(7.87)$ & $15.86^{* * *}(3.07)$ \\
\hline Observation & 3122 & 3122 \\
\hline Prob $>F$ & 0.0000 & 0.0000 \\
\hline$R^{2}$ & 0.6515 & 0.8969 \\
\hline
\end{tabular}

Note: ${ }^{*} p<0.05 ;{ }^{* *} p<0.01 ;{ }^{* * *} p<0.001$. 
0.77 and 0.97 ), but still remains substantial and points toward the floating effect (Dahlgaard et al., 2017). At the same time, the variable related to the host-country context is strongly predictive of the external vote share of a party, but only for the support expressed among the external community living in that host-country (and not in the home-country), as it should be. In addition, Table 3 confirms that being an incumbent party in the home-country does not affect directly this party's external vote share, but well its score among national voters. The negative sign of the coefficient for the national community suggests nonetheless that voters at home are overall more likely to sanction than reward a governing party. As expected too from the results of the SUR, we did not find the incumbency of ideologically similar parties in the host-country to affect directly the external vote share of a party in the elections of the home-country.

This regression test confirms that external voting choices are influenced by the homecountry politics and can therefore be predicted based on the home electoral behaviours. It points also to a simultaneous, though less powerful predictive effect of the new political context as external voters could favour in their home-country elections parties that are quite similar to those electorally rewarded and performing well in their new environment.

\section{Discussion}

Our comparative study acknowledges that the electoral behaviours of European citizens living abroad are both shaped by two different but complementary political contexts, i.e. the politics of their home and their new country. Overall, the analysis yields findings emphasising that external voting choices must be understood as hybrid outcomes: they are influenced by the way the home and the host-country electorates support political parties, with a much stronger effect of the public opinion in the country of origin. This article provides thus an original contribution to this literature stressing, usually through case-studies, that the political context in the origin and the new country of residence shape significantly migrants' political participation toward their home-country after their settlement in another country (Bermudez, 2010; Fitzgerald, 2004; Levitt \& Glick Schiller, 2008; Morawska, 2003; Tsuda, 2012). In the future, taking into consideration this duality appears a promising way to advance our knowledge of external voters in Europe and elsewhere in the world.

Relying mostly on case-oriented studies though, the literature has questioned also whether being a governing party at home could have a direct impact on the external vote share registered by this party and therefore on the choices expressed from abroad by external voters (Battiston \& Mascitelli, 2008; Boccagni \& Ramirez, 2013; Goldberg \& Lanz, 2019; Lawson, 2003; Mencutek, 2015; Sevi et al., 2020). In contrast to a direct effect, our study shows that being an incumbent party cannot alone account for the likelihood of this party to score higher among the external community. The impact of incumbency on the external vote share of a party emerges significantly only when another, mediator variable is taken into consideration: the support expressed for this party among the home voters. In other words, being a governing party has first the power to increase or decrease the support of a party in pre-electoral opinion polls, depending on how good or bad is evaluated this party by the electorate in the home-country, which will then affect in the very same direction this party's vote share among the external 
community. This finding is crucial since it means, first, that external voters will tend to favour an incumbent party only if it is well forecasted in the polls and that the home population supports it. Second, it confirms that external voters do remain connected to their home fellows and their governmental evaluations since they follow the flow of public opinion when casting a vote in home-elections from abroad.

Moreover, we provide evidence showing that the external vote share of a party in home-election might be driven also by the incumbency of ideologically similar parties in the new country of residence. Yet, this effect appears also indirect and mediated by how much a governing party is rewarded for its performances. Being a governing party in the host-country increases or decreases the electoral performances of this party, depending on the positive or negative evaluations of the country voters. Then, the external vote share of the ideologically similar party running the home-election is affected in the same direction. This finding is in line with the literature showing that the effect of incumbency in home-election can be different depending on the country of residence and more largely that new context of residence does affect the way external voters express themselves in home-elections (Sevi et al., 2020).

A major limitation to the present study lies in the use of aggregate data and the implicit interpretations made from an individual perspective. Indeed, the analysis can not account for patterns where voters are not born and/or have never socialised in the home-country, even if they have voting rights in that country. They cannot either consider the time spent in the new country of residence. These considerations push us to be cautious regarding the effect of both contexts. That is the reason why we strongly advocate in favour of coordinating efforts to get comparable, systematic individuallevel data on external voters in the future. It is only through such further scientific efforts that scholars will be able to fully untangle the dynamics shaping external voting choices, not only among the non-residents in Europe, but also, more largely, among any other migrants' community in the world.

\section{Conclusion}

While States have increasingly enfranchised non-resident citizens, this article aimed at analysing the voting choices made by non-resident European citizens when they take part in elections of their origin country from abroad. Relying on a comparison of aggregate election data covering 6 home-countries, 28 host-countries, across more than 20 years of elections, we developed a mediation model that sought to assess the influence of the politics in the home and the host-country by testing how the external vote share of a (governing) party in home elections was affected by the share received in the opinion polls at home and the support of the ideologically close parties in the 'new' country of residence.

The related findings show that external voters are hybrid voting creatures. Their choices are influenced by home politics and follow the choices that are intended to be made by the citizens living in the home-country. However, external voters are also impacted by the politics in their new country of residence. Their behaviours in home elections are also driven by the preferences expressed in the host-country.

Furthermore, we contributed to emphasise that party incumbency matters only indirectly and that its impact on the external vote share of a party is mediated by the 
support for this party in the home-country, or for ideologically similar parties in the hostcountry. Indeed, we show that a governing party is more likely to be voted among the external community if this party is positively forecasted in the opinion polls, meaning that it is rewarded for its government performances among the home-electorate. This observation stresses, even more, the influence of the home context and the fact that external voters remain connected to their home community and the flow of public opinion within the latter. Simultaneously, emphasising even the effect of the new context, we reveal that, when an incumbent party performs well in the elections of the hostcountry, meaning that the voters in this country reward this party for its results in government, then the external vote share of an ideologically similar party running the home elections increases. Overall, these findings point out that external voters do not blindly vote from abroad: their choices follow the flows of the public opinion at home and in the host-country.

\section{Notes}

1. See the Datasets' section in the bibliography.

2. See the Datasets' section in the bibliography.

3. We took systematically the closest election in the new country of residence, which precedes the one of interest in the home-country. The difference ranges between 0 years, meaning that these two elections were held the same year, to 5 years for those elections the most distant in time. When it comes to European elections, we considered the results of the same European election in the other 27 European countries, providing here two synchronic comparison points.

4. We used the following broad ideological party families: conservative, extreme-right, liberal, green, radical left, social democratic and other (encompassing minor or major populist parties that are difficult to categorise).

5. Please note that for each equation, a set of covariates is specified (see Appendix 1. Control variables).

6. Note: the full outcomes of the model are proposed in the table displayed in the Appendix 2 (Outcomes of the General Model).

\section{Acknowledgements}

The authors would like to thank the editors of the special issue (Emilie Van Haute and Tudi Kernalegenn) and the anonymous reviewers for their insightful comments.

\section{Disclosure Statement}

No potential conflict of interest was reported by the author(s).

\section{Funding}

The authors did not receive any support for the research, authorship and/or publication.

\section{Notes on Contributors}

Marco Ognibene is a PhD Student at Université libre de Bruxelles, Department of Political Science. His research interest includes the voting behaviour and the political participation. A particular 
focus is taken on migrants' electoral behaviour. In addition, he is a research assistant for the FAR Project that seeks to examine the attitudes towards political violence in Belgium. Email: marco. ognibene@ulb.be

Emilien Paulis is a postdoctoral researcher at Université libre de Bruxelles, Department of Political Science. His research interest includes political parties and political behaviour with a special methodological focus on the use of social network analysis. He currently works in the ERC Project on democratic innovation.

\section{Data Availability Statement}

The data used in this article are now pre-registered on Harvard Dataverse. They will be fully available once the submission decision has reached the authors.

\section{Data Deposition}

The data used in this article have been registered on a public data repository (Harvard Dataverse). Any use or replication must refer to Ognibene M. \& Paulis E. External Voting Dataset. Harvard Dataverse. DOI: https://doi.org/10.7910/DVN/0SKWK1

\section{ORCID}

Marco Ognibene (D) http://orcid.org/0000-0002-4142-6046

Emilien Paulis (D) http://orcid.org/0000-0001-5954-4182

\section{References}

Arrighi, J. T., \& Bauböck, R. (2017). A multilevel puzzle: Migrants' voting rights in national and local elections. European Journal of Political Research, 56(3), 619-639.

Ban, P., Llaudet, E., \& Snyder, J. M. (2016). Challenger quality and the incumbency advantage. Legislative Studies Quartely, 41(1), 153-179.

Battiston, S., \& Mascitelli, B. (2008). The challenges to democracy and citizenship surrounding the vote to Italians overseas. Modern Italy, 13(3), 261-280.

Bauböck, R. (2003). Towards a political theory of migrant transnationalism. The International Migration Review, 35(8), 700-723.

Bauböck, R. (2005). Expansive citizenship: Voting beyond territory and membership. PS: Political Science \& Politics, 38(4), 683-687.

Belton, K. A. (2019). Muddy waters: Citizenship and the right to vote in the Commonwealth Caribbean migratory context. Commonwealth \& Comparative Politics, 57, 93-122.

Berinsky, A. J. (2017). Measuring public opinion with surveys. Annual Review of Political Science, 20, 309-329.

Bermudez, A. (2010). The transnational political practices of Colombians in Spain and the United Kingdom: Politics "here" and "there". Ethnic and Racial Studies, 33(1), 75-91.

Bermudez, A., \& Lafleur, J. M. (2015). Diaspora contributions to democratic processes at home: The external vote of andean migrants. Congrès AFSP Aix 2015.

Blais, A. (2000). To vote or not to vote: The merits and limits of rational choice theory. University of Pittsburgh Press.

Boccagni, P. (2011). Reminiscences, patriotism, participation: Approaching external voting in Ecuadorian immigration to Italy. International Migration, 49(3), 76-98.

Boccagni, P., \& Ramirez, J. (2013). Building democracy or reproducing 'Ecuadoreanness'? A transnational exploration of Ecuadorean migrants' external voting. Journal of Latin American Studies, 45(4), 721-750. 
Brand, L. (2010). Authoritarian States and voting from abroad. Comparative Politics, 43(1), 81-99.

Brand, L. A. (2014). Arab uprisings and the changing frontiers of transnational citizenship: Voting from abroad in political transitions. Political Geography, 41, 54-63. doi:10.1016/j.polgeo.2013. 11.00

Brown, T. A. (1988). Migration and politics: The impact of population mobility on American voting behaviour. The University of North Carolina Press.

Burgess, K. (2018). States or parties? Emigrant outreach and transnational engagement. International Political Science Review, 39(3), 369-383.

Burgess, K., \& Tyburiski, M. D. (2020). When parties go abroad: Explaining patterns of extraterritorial voting. Electoral Studies, 66, 1-11.

Chaudary, A. R. (2018). Voting here and there: Political integration and transnational political engagement among immigrants in Europe. Global Networks: A Journal of Affairs, 18(3), 437460.

Ciornei, I., \& Østergaard-Nielsen, E. (2020). Transnational turnout. Determinants of emigrant voting in home country elections. Political Geography, 78, 102-145.

Collyer, M. (2014). A geography of extra-territorial citizenship: Explanations of external voting. Migration Studies, 2(1), 55-72.

Crissey, S., \& File, T. (2012). Voting behaviour of naturalized citizens: 1996-2010. US Census Bureau.

Dahlgaard, J. O. (2016). You just made it: Individual incumbency advantage under proportional representation. Electoral Studies, 44, 319-328.

Dahlgaard, J. O., Hansen, J. H., Hansen, K. M., \& Larsen, M. V. (2017). How election polls shape voting behaviour. Scandinavian Political Studies, 40(3), 330-343.

Earnest, D. C. (2015). Expanding the electorate: Comparing the noncitizen voting practices of 25 democracies. Journal of International Migration and Integration, 16, 1-25.

Ellis, A., Navarro, C., Morales, I., Gratschew, M., \& Braun, N. (2007). Voting from abroad: The international IDEA handbook. Intl Idea.

Eurostat. (2018). 2017 annual report on intra-EU labour mobility. Final Report January 2018. EuropeanCommission. https://ec.europa.eu/futurium/en/system/files/ged/2017_report_on_ intraeu_labour_mobility.pdf

Escobar, C., Renelinda, A., \& McCann, J. A. (2015). Expatriate voting and migrants' place of residence: Explaining transnational participation in Colombian elections. Migrant Studies, 3(1), 1-31.

Faist, T. (2000). The volume and dynamics of international migration and transnational social spaces. Oxford University Press.

Fidrmuc, J., \& Doyle, O. (2006). Does where you live affect how you vote? An analysis of migrant voting behaviour.

Finifter, A. W., \& Finifter, B. M. (1989). Party identification and political adaptation of American migrants in Australia. The Journal of Politics, 51(3), 599-630.

Finn, V. (2020). Migrant voting: Here, there, in both countries, or nowhere. Citizenship Studies, 24 (6), 730-750.

Fitzgerald, D. (2004). Beyond 'transnationalism': Mexican hometown politics at an American labour union. Ethnic and Racial Studies, 27(2), 228-247.

Fiva, J., \& Smith, D. (2018). Political dynasties and the incumbency advantage in party-centered environments. American Political Science Review, 112(3), 706-712.

Fox, J. (2005). Unpacking transnational citizenship. Annual Review of Political Science, 8, 21-171.

Gamlen, A. (2018). Why engage diasporas? In R. Cohen \& C. Fischer (Eds.), Routledge handbook of diaspora studies (p. 382). Routledge.

Goldberg, A. C., \& Lanz, S. (2019). Living abroad, voting as if at home? Electoral motivations of expatriates. Migration Studies, 9(2), 1-32.

Green, W. H. (2017). Econometric analysis (8th ed.). Pearson.

Guarnizo, L. E., Chaudary, A. R., \& Sørensen, N. N. (2017). Migrants' transnational political engagement in Spain and Italy. Migration Studies, 7(3), 281-322. 
Guarnizo, L. E., Portes, A., \& Haller, W. (2003). Assimilation and transnationalism: Determinants of transnational political action among contemporary migrants'. In S. Khagram \& P. Levitt (Eds.), The transnational studies reader: Intersections and innovations (pp. 118-134). Routledge.

Hartmann, C. (2015). Expatriates as voters? The new dynamics of external voting in sub-Saharan Africa. Democratization, 22(5), 906-926.

Hayes, A. F. (2018). Introduction to mediation, moderation and conditional process analysis. A regression-based approach (2nd ed.). The Guilford Press.

Hicks, R., \& Tingley, D. (2011). Causal mediation model. Stata Journal, 11(4), 1-15.

Honaker, J., King, G., \& Katz, J. N. (2002). A fast, easy, and efficient estimator for multiparty electoral data with improved lemon scent. Political Analysis, 10(1), 84-100.

Hutcheson, D. S., \& Arrighi, J. T. (2015). Keeping Pandora's (ballot) box half-shut": A comparative inquiry into the institutional limits of external voting in EU member states. Democratization, 22 (5), 884-905.

Itzigsohn, J., Dore Cabral, C., Medina, E. H., \& Vazquez, O. (1999). Mapping Dominican transnationalism: Narrow and broad transnational practices. Ethnic and Racial Studies, 2(2), 319-339.

Jaulin, T. (2016). Geographies of external voting: The Tunisian elections abroad since the 2011 uprising. Comparative Migration Studies, 41(1), 4-14.

Jaulin, T., \& Smith, E. (2015). Généralisation et pratiques du vote à distance. Introduction thématique. Afrique Contemporaine, 256(4), 11-34.

Jones-Correa, M. (2001). Institutional and contextual factors in immigrant naturalization and voting. Citizenship Studies, 51(1), 41-56.

Kernalegenn, T., \& van Haute, E. (2020). Political parties abroad. A new arena for party politics. Routledge.

Kivisto, P. (2001). Theorizing transnational immigration: A critical review of current efforts. Ethnic and Racial Studies, 24(4), 549-577.

Klasnja, M., \& Titiunik, R. (2017). The incumbency curse: Weak parties, term limits, and unfulfilled accountability. American Political Science Review, 111(1), 129-148.

Knott, E. (2017). The extra-territorial paradox of voting: The duty to vote in extra-territorial elections. Democratization, 24(2), 325-345.

Lafleur, J. M. (2011a). Exporting ethnic division? The political participation of Belgian citizens abroad.

Lafleur, J. M. (2011b). Why do states enfranchise citizens abroad? Comparative insights from Mexico, Italy and Belgium. Global Networks: A Journal of Transnational Affairs, 11(4), 481-501.

Lafleur, J. M. (2015). The enfranchisement of citizens abroad: Variations and explanations. Democratization, 22(5), 840-860.

Lafleur, J. M., \& Calderon, C. (2011). Assessing emigrant participation in home country elections: The case of Mexico's 2006 presidential election. International Migration, 43(9), 99-124.

Lafleur, J. M., \& Sanchez-Dominguez, M. (2015). The political choices of emigrants voting in home country elections: A socio-political analysis of the electoral behaviour of Bolivian external voters. Migration Studies, 3(2), 155-181.

Lawson, C. (2003). Voting preference and political socialization among Mexican Americans and Mexicans living in the United States. Mexican Studies/Estudios Mexicanos, 19(1), 65-79.

Leal, D. L., Lee, B. J., \& McCann, J. A. (2012). Transnational absentee voting in the 2006 Mexican presidential election: The roots of participation. Electoral Studies, 31(3), 540-549.

Levitt, P., \& Glick Schiller, N. (2008). Conceptualizing simultaneity: A transnational social field perspective on society. In S. Khagram \& P. Levitt (Eds.), The transnational studies reader: Intersections and innovations (pp. 129-156). Palgrave.

McIlwaine, C., \& Bermudez, A. (2015). Ambivalent citizenship and extraterritorial voting among Colombians in London and Madrid. Global Networks: A Journal of Transnational Affairs, 15(4), 385-402.

Mencutek, Z. S. (2015). External voting: Mapping motivations of emigrants and concerns of host countries'. Insight Turkey, 17(4), 145-169.

Morales, L., \& Giugni, M. (2011). Social capital, political participation and migration in Europe making multicultural democracy work? Palgrave Macmillan UK. 
Morawska, E. (2003). Immigrant transnationalism and assimilation: A variety of combinations and a theoretical model they suggest. In C. Joppke \& E. Morawska (Eds.), Toward assimilation and citizenship: Immigrants in liberal nation-states (pp. 133-176). Palgrave.

Morwitz, V. G., \& Pluzinski, C. (1996). Do polls reflect opinions or do opinions reflect polls? The impact of political polling on voters' expectations, preferences, and behavior. Journal of Consumer Research, 23(1), 53-67.

Nanestad, P., Paldam, M., \& Rosholm, M. (2003). System change and economic evaluations: A study of immgrants and natives in Israel. Electoral Studies, 22(3), 485-501.

Østergaard-Nielsen, E., \& Ciornei, I. (2018). Political parties and the transnational mobilisation of the emigrant vote. West European Politics, 42(3), 618-644.

Østergaard-Nielsen, E., Ciornei, I., \& Lafleur, J. M. (2019). Why do parties support emigrant voting rights? European Political Science Review, 11(3), 377-394.

Portes, A. (1998). Globalization from below: The rise of transnational communities. ESRC Transnational Communities Programme.

Rashkova, E. R., \& Van Der Staak, S. (2019). The party abroad and its role for national party politics. In International IDEA Discussion Paper 1.

Rubio-Marin, R. (2006). Transnational politics and the democratic nation-state. Normative challenges of expatriate voting and nationality retention of emigrants. New York University Law Review, 81, 117-147.

Salas, C. (2016). Incumbency advantage in multi-member districts: Evidence from congressional elections in Chile. Electoral Studies, 42, 213-221.

Sevi, S., Mekik, C. S., Blais, A., \& Çakır, S. (2020). How do Turks abroad vote? Turkish Studies, 21 (2), 208-230.

Tager, M. (2006). Expatriates and elections. Diaspora: A Journal of Transnational Studies, 15(1), $35-60$.

Tintori, G. (2012). Il voto degli altri: rappresentanza e scelte elettorali degli italiani allestero. Rosenberg \& Sellie.

Tsuda, T. (2012). Whatever happened to simultaneity? Transnational migration theory and dual engagement in sending and receiving countries. Journal of Ethnic and Migration Studies, 38 (4), 631-649.

Turcu, A., \& Urbatsch, R. (2014). Diffusion of diaspora enfranchisement norms: A multinational study. Comparative Political Studies, 48(4), 407-437.

Uppal, Y. (2009). The disadvantaged incumbents: Estimating incumbency effects in Indian state legislatures. Public Choice, 138, 9-27.

Vertovec, S. (1999). Conceiving and researching transnationalism. Ethnic and Racial Studies, 22 (2), 447-463.

Waldinger, R., \& Fitzgerald, D. (2004). Transnationalism in question. American Journal of Sociology, 109(5), 1177-1195.

\section{Datasets}

2017 annual report on intra-EU labour mobility. Final Report January 2018. European Commission. https://ec.europa.eu/futurium/en/system/files/ged/2017_report_on_intra-eu_ labour_mobility.pdf;

ParloGov. http://www.parlgov.org/

Manifesto data project. https://manifesto-project.wzb.eu/;

Croatian Electoral Commission. https://www.izbori.hr/site/;

Czech Republic Official Statics https://www.czso.cz/;

National Czech Newspaper : Idnes https://www.idnes.cz/volby/parlamentni;

French Interior Minister. https://www.interieur.gouv.fr/Archives/Archives-elections;

Italian Interior Minister. http://elezionistorico.interno.gov.it/index.php?tpel=C;

Polish Electoral Archive. https://wybory.gov.pl;

Polish National Electoral Commission: https://www.pkw.gov.pl/;

Permanent Electoral Authority. https://www.roaep.ro/prezentare/istoric_electoral/; 


\section{Appendices}

\section{Appendix 1. Control Variables}

For each equation, we consider a specific set of covariates to see whether our results were stable across countries, and thereby making emerge the expected regular patterns among European external voters. Although each of these covariates has been shown (1) to affect the external voters' level of electoral mobilisation or (2) the propension for incumbent parties to be rewarded or sanctioned in national elections, we did not expect them to affect directly the vote share taken by a party among the external community. It seemed nonetheless important to include them as controls. For the VoteSharePolls $(\log )$ equation, we have introduced controls related to the homecountry: the ideological family of the parties, the geographical location of the country (i.e. whether it is a Western or Eastern European country), the type of the home-country election (i.e. legislative, presidential or European elections), the GDP growth, the unemployment rate in the year preceding the elections and the year external voting rights have been adopted. Similarly, for the VoteShareHost $(\log )$ equation, we have added controls for the new country of residence: the ideological family of the parties, the geographical location of the country, the type of elections, the GDP growth, and the unemployment rate in the year preceding the host-country elections. Finally, for the VoteShareAbroad $(\log )$ equation, all the control variables presented above have been added to the model.

\section{Appendix 2. Outcomes of the General Model}

Table A2. Seemingly unrelated regression model for external voting choices with 5000 bootstrap.

\begin{tabular}{|c|c|c|c|}
\hline & $\begin{array}{c}\text { Model } 1 \\
\text { (Home-country) }\end{array}$ & $\begin{array}{c}\text { Model } 2 \\
\text { (Host-country) }\end{array}$ & $\begin{array}{c}\text { General model } \\
\text { (Both countries) }\end{array}$ \\
\hline IncumbentHome & $.38^{* * *}(0.04)$ & - & $-.05(0.04)$ \\
\hline VoteSharePolls(log) & - & - & $.77^{* * *}(0.02)$ \\
\hline IncumbentHost & - & $.29^{* * *}(0.04)$ & $.05(0.04)$ \\
\hline VoteShareHost(log) & - & - & $.07^{* * *}(0.02)$ \\
\hline \multicolumn{4}{|c|}{ Ideological Family (Ref. Conservative) } \\
\hline Extreme-Right & $-1.85^{* * *}(0.05)$ & $-1.50^{* * *}(0.05)$ & $-1.05^{* * *}(0.07)$ \\
\hline Green & $-3.01 * * *(0.07)$ & $-2.07^{* * *}(0.08)$ & $.30^{* *}(0.11)$ \\
\hline Liberal & $-1.97^{* * *}(0.06)$ & $-1.16^{* * *}(0.05)$ & $.04(0.07)$ \\
\hline Radical Left & $-1.80^{* * *}(0.06)$ & $-1.69^{* * *}(0.08)$ & $-.83^{* * *}(0.10)$ \\
\hline Social Democratic & $-.73^{* * *}(0.04)$ & $-.42^{* * *}(0.04)$ & $-.87^{* * *}(0.05)$ \\
\hline Other Parties & $-1.28^{* * *}(0.08)$ & $-1.06^{* * *}(0.08)$ & $-.48^{* * *}(0.09)$ \\
\hline \multicolumn{4}{|c|}{ Geograph - Home (Ref. Western Country) } \\
\hline \multicolumn{4}{|c|}{ Geography - Host (Ref. Western Country) } \\
\hline Eastern Country - Host & - & - & $.02(0.04)$ \\
\hline \multicolumn{4}{|l|}{ Type of Election (Ref. Legislative) } \\
\hline Presidential & $.30 * * *(0.05)$ & $.01(0.04)$ & $-.76^{* * *}(0.10)$ \\
\hline European & $.22^{* * *}(0.03)$ & $-.08 *(0.04)$ & $-.19^{* * *}(0.04)$ \\
\hline GDP Growth - Home & $.03^{* * *}(0.01)$ & - & $.003(0.01)$ \\
\hline Unemployment Rate - Home & $-.01(0.04)$ & - & $.03^{* * *}(0.005)$ \\
\hline GDP Growth - Host & - & $.003(0.04)$ & $.0003(0.004)$ \\
\hline Unemployement Rate - Host & - & $-.003(0.004)$ & $.01 *(0.003)$ \\
\hline External Voting Rights - Home & - & - & $-.02^{* * *}(0.004)$ \\
\hline Constant & $-.87^{* * *}(0.07)$ & $-.91^{* * *}(0.06)$ & $36.54^{* * *}(7.87)$ \\
\hline Observation & 3122 & 3122 & 3122 \\
\hline Prob $>F$ & 0.0000 & 0.000 & 0.0000 \\
\hline$R^{2}$ & 0.6019 & 0.3997 & 0.6515 \\
\hline
\end{tabular}

Note: ${ }^{*} p<0.05 ;{ }^{* *} p<0.01 ;{ }^{* *} p<0.001$. 